\title{
Students' Speaking Anxiety in English Class
}

\author{
Atanasius Gabe Hardional Sinaga \\ English Education Study Program, Department of Language and Art \\ University of Bengkulu \\ atanasiusgabe@gmail.com \\ Syahrial \\ English Education Study Program, Department of Language and Art \\ University of Bengkulu \\ eric.syahrial@gmail.com \\ Gita Mutiara Hati \\ English Education Study Program, Department of Language and Art \\ University of Bengkulu \\ gitamutiara@unib.ac.id
}

\begin{abstract}
This research aimed to find out the level of students' speaking anxiety students in English class and the most dominant factors that caused students' speaking anxiety faced by the third grade students of Junior High School in SMPN 15 Bengkulu in English Classroom. This research used descriptive quantitative design with questionnaire as the instrument. The questionnaire of this research was Foreign Language Classroom Anxiety Scale (FLCAS) proposed by Horwitz et al. (1983). The data has been analyzed by using SPSS program. The population of this research was the third grade students in SMPN 15 Bengkulu. The total is 7 classes: class A, Class B, Class C, Class D, Class E, Class F, and Class G. The total number of population is 163 students. From 7 classes, the researcher decided to take only $20 \%$ of student each. The result of this research showed that the majority of the students of the third-grade were Mildly Anxious level and the most dominant factors causing the student speaking anxiety was the Fear of Negative Evaluation. According to the result, most of the students were already feel anxious about the fact that they had to speak in a group or individually and also being evaluated by the teacher in front of the English class. In conclusion, the researcher found that students are afraid to speak up in front of the class because they always think that other students will laugh at them and judge the student who speaks in front of the class. This might make the student's speaking anxiety arise and make them to stay silent instead of speaking.
\end{abstract}

Keywords: Speaking Anxiety, Anxiety Level, Anxiety Factors

\section{A. Introduction}

Communication in a foreign language sometimes can be a stressful activity for the learners because they are used to using their first or mother tongue language and they have to speak the language that is not their first or mother tongue. Speaking is one of English skills that could deliver and express the ideas of the communicant (Diani, et al., 2019; Syafryadin, et al., 2013; Syafryadin, et al., 2020; Noermanzah, et al; 2020). Besides, speaking can contain the structure of the rhetoric that could make someone feel afraid of speaking because speaking had many elements that must be mastered (Noermanzah, et al; 2020; Syafryadin, 
2020). "Speaking in the target language seems to be threatening aspect of foreign language learning", stated by Horwitz et al.(1986). The learners also have a small chance to practice English outside the classroom because English is not their first language which can make the students feel anxious in English language learning, especially in speaking skill regarding to the small chances to practice it.

One of the most well documented psychology phenomena that occur in everyday life is known as Anxiety. Passer and Smith (2009) stated that anxiety as a state of tension and apprehension as a natural response to perceived threat. In general explanation, this psychology phenomenon seems to appear as the response to particular condition. In common, anxiety is known as a feeling of being threatened, apprehension, tension, worry, or depression. According to Zhang and Zhong (2012), the main cause of anxiety stems from “learners' unrealistic or erroneous beliefs about language learning. Student probably is having more than one of anxiousness, and this will influence student's language learning process. Halgin and Whitbourne (2007) described the difference between fear andanxiety.Fearisanaturalalarmresponsetoadangeroussituationwhileanxiety is more futureoriented situation, a feeling of apprehension and nervousness about the possibility of something terrible that might be happen in the future.

Foreign language anxiety is a common phenomenon for foreign language learners. Thus, the researcher believe that it is important to observe the speaking anxiety experienced by students in English class since speaking is an activity that contributes the greatest anxiety for foreign language learners. (Gardner \& Maclntyre, 1993:5) defined foreign language anxiety as an apprehension experienced when a situation requires the use of a second language with which the individual is not fully proficient.A result of FLSA in English classroom by Keramida (2009) also show that students in the third grade of lower secondary school in Greece experienced FLSA because they were afraid that their peers will evaluate them negatively and consider them as a low ability students.According to (Phillips, 1992), high levels of anxious student usually avoid the foreign language class or remove the courses that having a communication requirement.

There are two kinds of anxiety that have been described. State anxiety and Trait anxiety are the most well-known. First is State anxiety, State anxiety will arise if a person confronted with specific situation. People mostly experienced state anxiety which is also known as a normal anxiety. According to Ormrod (2011), anxiety is temporary feeling of anxiety emerged by a threatening situation. It is nervousness or tension at a particular moment 
in response to some outside stimulus. The second is Trait anxiety. According to Ormrod(2011),trait anxiety as a pattern of responding with anxiety even in non-threatening situations. Brown (1994) also stated that trait anxiety is more permanent predisposition to be anxious. In this case, someone with trait anxiety experiences anxiety every time or anxiety that comes more intense and lasted for long.

Horwitz et. al (1986) classified foreign language anxiety into three types, first is communication anxiety. Communication anxiety is a type of shyness characterized by fear of or anxiety about communicating with people. And next is fear of negative evaluation, an apprehension about others' evaluative situations, avoidance of evaluative situations, and the expectation that others would evaluate oneself negatively. And the last is test anxiety, a type of performance anxiety stemming from a fear of failure.

On the level of junior high school students, English is a subject that most students do not like because they have to use a foreign language that is very different from their mother tongues language, especially in speaking term. Many students are not feeling confident and keep feeling anxious with their performance in front of the class when the teacher calls their name to speak about English lessons. One factor that significantly affects students in speaking is fear of negative evaluation. Even though the teacher has teach the students about the instructions and how to speak fluently and well, many factors such like fear of negative evaluation, fear of being less competent than other students, fear of taking risks, lack of preparation, lack of vocabulary and other students' evaluation about one student speaking ability.

There were several previous studies related to this research. First is the research from Ati Saidatul Ula (2016). The aims of Ula's research are To investigate the level of anxiety experienced by the 2nd semester students of International Class Program of IAIN Salatiga in English speaking class and to figure out the description of studentse speaking ability from their anxiety level of the 2nd semester students of International Class Program of IAIN Salatiga. The result of her research showed that there were 17 students who had different levels of anxiety in speaking skill. [1] There were 5 students (29\%) who experience "Anxious" level, and the range score for "Anxious" level started from 108-123. [2] There were 9 students (53\%) are in 54 "Mildly Anxious" level, it means a half of the respondents are in range score 87-107. [3] There were 2 students (12\%) that had "Relaxed" level, and the range score of this level is started from 66-86. [4] Only 1 student (6\%) from 17 students is in "Very Relaxed" level, which the range score started from 33-65. The researcher found that 
there were no respondents who are in "Very Anxious" level in this research.

The second previous research was from Cucu Sutarsyah (2017). The aims of Sutarsyah's research are to seek if there is a negative psychological factor known as anxiety could really affect students' speaking performance and to find the difference in speaking performance between students with higher level of anxiety and students with lower level of anxiety and also to seek which of the factors of anxiety is dominant. The first finding showed that students with lower level of anxiety gave a better result with their speaking test than those who have higher level of anxiety. In other words, the students with good speaking performance tend to have less anxiety; they feel confidence with their performance. Another finding of this research derived from the second hypothesis was that anxiety gave quite contribution to the students' speaking performance. Students with medium level of anxiety were quite adequate level to perform speaking task as their score in speaking performance itself was satisfied enough for their level. Medium level of anxiety could only affect a little to their speaking performance.

The third previous research was from Catur Widyasworo (2019). The aims of Widyasworo's research are find out the students' difficulties in speaking, and to describe strategies used by teacher to overcome the speaking problems. The firs finding showed that the students' difficulties in speaking English consist of linguistics and non-linguistics problems. Linguistics problems are vocabulary, grammar, and pronunciation. Nonlinguistic problems are inhibition, nothing to say, uneven participant, and mother tongue, anxiety, shyness, lack of self-confident and low of motivation. The second finding showed that strategies used by English teacher in teaching speaking are Role Play, Drilling, Brainstorming, and Give the Students Motivation.

The fourth previous research was from Tesalonika Mayangta (2013). The aims of Mayangta's research are to find out levels of anxiety experienced by the students in English speaking class, the sources that contribute to students' speaking anxiety, and strategies do the students apply to reduce their anxiety. The first finding showed that most of the students are at mildly anxious level of anxiety with no very relaxed student. The second finding showed that students' sources of anxiety in speaking are varied such as personal and interpersonal anxieties, students' beliefs about language learning, instructor-learner interactions, classroom procedures and perceived levels of English proficiency are the sources of speaking anxiety in the current research. The third finding showed that coping strategies applied by the students to reduce their anxiety in speaking. Therefore supportive and relaxing classroom atmosphere 
is needed to be created by the English teacher by being more as a facilitator than an absolute educator, giving new insights and information of language learning, encouraging the students to be more confident and giving suited error corrections.

The fifth previous research was from Aisyah Amini, Elfrida, and Kasmaini (2019). The aims of their research is to find out whether there is a correlation between students' anxiety level and oral presentation's performance in EFL speaking class. The finding of the research based on rater 1 or rater 2 score, there was a significant correlation between students' anxiety level and oral presentation performance in EFL speaking class on the 4th semester students of English Education Study Program of Bengkulu University based on the sig.2-tailed (0.000). Therefore, the correlation showed negative direction. Negative correlation or inverse correlation is a relationship between two variables which move in opposite direction. If variables $\mathrm{X}$ and $\mathrm{Y}$ have a negative correlation (or a negatively correlated), as X increases in value, Y will decrease. Similarly, if X decreases in value, Y will decrease. In this research, if the students' anxiety levels were high, the presentation score will be low and vice versa.

Because the problem above, the reason why the researchers conducts this research is because the researcher has not found similar study about speaking anxiety in Bengkulu, especially on SMPN 15 Bengkulu. Therefore, the objective of the research was to find out what are the levels of students' speaking anxiety in English Class and to find out what is the dominant factors causing students' speaking anxiety in English Class.

\section{B. Research Method}

This research used descriptive quantitative, where the researchers presented data in numerical and descriptive form. Descriptive quantitative was used in this research because the data obtained by the researcher based on quantitative data, then the researcher explains the results of the data into descriptive form. Susetyo (2015) stated that descriptive quantitative research design is conducted to investigate the actual problem that is currently happened.

The populations of this research are the third grade students in SMPN 15 Bengkulu. The total is 7 classes: class A with 23 students, Class B with 24 students, Class C with 24 students, Class D with 23 students, Class E with 23 students, Class F with 23 students, and Class $\mathrm{G}$ with 24 students. The total number of population is 163 students. From 7 classes, the researcher decided to take $40-50 \%$ of students each class to represent their own class. The 
research used random sampling technique.

To collect the data from the subject, the researcher distributed the questionnaires adapted by Horwitz et al. (1986). The FLCAS questionnaire administered to the third grade SMPN 15. After that, the administered questionnaire will be collected by the researcher. After collecting the data, the researcher analyzed the data, the obtained data described in the descriptive-quantitative form.

The instrument of this study is the Foreign Language Classroom Anxiety Scale (FLCAS) proposed by Horwitz et al. (1983). In this research, the researcher uses a translated version of the original questionnaire. This instrument consists of 33 questions about anxiety in classroom. This instrument was chosen because "it employs a situation specific approach, an approach which has yielded more meaningful and consistent results than other approaches in second language speaking anxiety studies" (Mak, 2009). The FLCAS questionnaire consists of two statements which are positive and negative. The positive range will be ranged from 5-1 as represent "Strongly Disagree" to "Strongly Agree". While, the negative statement will be ranged from 1-5 as represent "Strongly Agree" to "Strongly Disagree". There are 9 positive statements in the questionnaire which are number 2,5,8,11,14,18,22, 28, and32. While,thenegativestatementsareinnumber1,3,4,6,7,9,10,12, $13,15,16,17,19, \quad 20$, $21,23,24,25,26,27,29,30,31$, and 33. FLCAS was categorized into some levels of anxiety start from "Very Anxious", "Anxious", "Mildly Anxious", "Relaxed", and "Very Relaxed" based on Oetting's scale. The data has been analyzed by using SPSS program.

\section{Results and Discussion}

\section{Results}

The data has been gathered by the researcher for this research by using a research instrument, questionnaire adapted from Horwitz et.al (1986). The data of this research has been analyzed to obtain the mean and percentage level of the students' speaking anxiety and the most dominant factor causing it by using the SPSS program.

The first aim of this research is to find out the level of students' speaking anxiety in English class. The level of students' speaking anxiety has been described by the researcher among the third grade students of Junior High School 15 Bengkulu. The general result of the research is showed in the following table: 
Table 1: The result of students' speaking anxiety level

\begin{tabular}{|c|c|c|}
\hline Number Of Students & Percentage & Category \\
\hline 4 & $5.71 \%$ & Very Anxious \\
\hline 18 & $25.71 \%$ & Anxious \\
\hline 43 & $61.43 \%$ & Mildly Anxious \\
\hline 4 & $5.71 \%$ & Relaxed \\
\hline 1 & $1.43 \%$ & Very Relaxed \\
\hline
\end{tabular}

Based on the data showed in the table above, the result were as follows, 4 students (5.71\%) were indicated "Very Anxious", 18 students (25.71\%) were indicated "Anxious", 43 students (61.43\%) were indicated "Mildly Anxious", 4 students (5.71\%) were indicated "Relaxed", and 1 students (1.43\%) was indicated "Very Relaxed". From the data above, the researcher indicate that the majority of the students (43 out of 70) and also the overall anxiety level of the third grade students in Junior High School 15 Bengkulu was Mildly Anxious level.

For the second aim of this research, which is to find out the most dominant factor causing students' speaking anxiety in English Class. The researcher had found the factors causing the students were failing into speaking anxiety states. The researcher divided the result into three major causes; Test Anxiety, Communication Anxiety, and Fear of Negative Evaluation. The researcher create a table to make data simpler to determine the most dominant factor causing speaking anxiety in English Classroom as the conclusion of the result above. The data shows:

Table 2: The Result of Factors that Causing

Students' Speaking Anxiety in Classroom

\begin{tabular}{|c|c|c|}
\hline No. & Speaking Anxiety Group & Mean Score \\
\hline 1 & Fear Of Negative Evaluation & 3.44 \\
\hline 2 & Test Anxiety & 3.15 \\
\hline 3 & Communication Anxiety & 2.92 \\
\hline
\end{tabular}


We can take a conclusion from the table above that the most dominant factors causing the student speaking anxiety was the Fear of Negative Evaluation with mean score of 3.44. It is showed in the table above that the sources of the student speaking anxiety mostly came from negative evaluation and negative assessment about others students' performance in speaking, feeling distress over their pessimistic mind, and the expectation that others would evaluate themselves negatively.

\section{Discussion}

First Research Question: to find out the level of students' speaking anxiety in English Class

During the English Class, especially in speaking lesson, most of the students were already feel anxious about the fact that they had to speak in a group or individually and also being evaluated by the teacher in front of the English class. Even if they had been classmates from their first day in third grade, they had anxiety about what was to come in the class. They experienced the same thing, for example they would feel anxious whenever they were asked to speak because they felt that they were unprepared and that they were not confident with their English proficiency. And they also by showing several symptoms of nervousness such as accelerated heart rate, sweaty palms, and tightness in the stomach. Thus it was evident that they experienced speaking anxiety in English Classroom.

The first target of this research was to find out the level of students' speaking anxiety in English Class. The data already calculated with the range of score started from 33 to 165 . Based on the result in the table of students speaking anxiety level, the majority of the student (43 out of 70) are mildly anxious when it comes to speaking in English, which can be indicated as the overall level of speaking anxiety of the third grade of Junior High School 15 Bengkulu is Mildly Anxious level. This proved by Prince (1991) research which he noted that anxious students believe their language skills were weaker than the others. Followed by Alsowat (2016), the dominant causes of students' anxiety were worrying about the consequences of failing, forgetting things they know, and feeling uneasiness during language tests. This finding of this research are the same as Ula (2016) in which she found that more than $50 \%$ of her research respondents shows an anxiety level "Mildly Anxious".

\section{Second Research Question: to find out the most dominant factors causing students' speaking anxiety in English Class}

The second target of this research was to find out what is the most dominant factor 
that causing students' speaking anxiety in English Class. Fear of Negative Evaluation becomes the most dominant factor that cause speaking anxiety for the students. Based on (Daly, 1991, cited in Deyuan, 2011), foreign language speaking anxiety can be described as an individual's feeling of fear and anxiety in communicating orally. The result showed that the third-grade students mostly start to feel anxious when they have to speak in front of the class. The reasons were because they thinking of other students would evaluate and judge them for their performance and ability in speaking. This might happen because the students are fear of negative evaluation and judgment by others students by laughing at them and chuckle a little bit which makes the student who spoke in front of the class experience speaking anxiety to arise. In this sense, when they make a mistake in speaking, it is hard for them to feel confident and bold to speak in front of class anymore. They also feel nervous when the teacher called their name to be the first speaker to speak in front of the class. As soon as their teacher calls one student's name, the anxious feeling starts rising and makes the student feel nervous when they are going to be the first speaker in front of the class in English classroom. This happened because the students lack vocabulary, lack of pronunciation, and many of the student did not prepare the material properly a night before the oral test. It will cause them to feel nervous and makes their mind go blank or that they will forget what to say. Students who have this factor of anxiety feel unconfident when they have to talk using English language, and usually avoid the situation which could make them to speak English in the classroom which can impact their ability and comprehension in English classroom. Several similarities of the research can be found in term of results of research from several previous studies. Sutarsyah (2017) found that the dominant factors that caused anxiety were feeling nervous and followed by tension and worries.

The researcher assumed that what makes students speaking anxiety getting worse are those negative evaluation which comes from their friends or the teacher.

They also believed that "they should produce faultless sentences". Because when the anxious feeling is getting worse, the fear will be greater, and when fear becomes greater, it will impact greatly to students' performance in the classroom, especially when they have to speak in front of the class. The students also lack of controlling their fear of making mistake because they never realize about what they could achieve when they can control they fear. It is crucial for the students to realize that they have to control their fear and anxious feeling. Because when they can control it, they can change the fear into a great motivation and makes them brave to speak in front of the class without worrying making any mistakes. 
This finding of this research are the same as Ati Saidatul Ula (2016) in which she found that more than $50 \%$ of her research respondents shows an anxiety level "Mildly Anxious". She admits that she did not figure out the influence of students' anxiety level toward their speaking performance. She stated that it can be a normal condition when many people are also feeling tense or nervous when they have to perform something in front of other people (especially the lecturer/ teacher). She also pointed out her research gives a description that anxious students are not necessarily having low scores, and mildly anxious students might not always have a good score.

\section{Conclusion and Suggestion}

\section{Conclusion}

The researcher had already finished the research and found the levels of students' speaking anxiety in English Class and the most dominant factor that causing students' speaking anxiety in the third grade of Junior High School 15, the researcher draws a conclusion based on the research questions which were two conclusions. The first conclusion is the result of speaking anxiety levels among the third grade of Junior High School 15 Bengkulu in English classroom was in the level of Mildly Anxious, which also indicated that overall anxiety level of the third grade of Junior High School 15 Bengkulu was Mildly Anxious. The researcher found that students maybe afraid to speak up in front of the class because they always think that other students will laugh at them and judge the student who speaks in front of the class. This might make the student's speaking anxiety arise and make them to stay silent instead of speaking.

The second conclusion that the researcher obtained that there were several factors that causing students' speaking anxiety, experienced by the third grade of Junior High School 15 Bengkulu. And the most dominant factor that causing students' speaking anxiety was Fear of Negative Evaluation, because students sometimes think that the teacher will always correct whatever the students say in English classroom, especially in speaking and that makes them feel more anxious and afraid to start speaking in front of the class, just because they do not feel confident with their own ability in English speaking. It explains that students always look down on themselves and never had confident to speak English because when they do not feel confidence with their English speaking ability, students tend to be afraid to speak because they will receive a negative evaluation both from teacher and other students if they make an error while speaking. 


\section{Suggestion}

According on the result of this research, the researcher wants to give some suggestions for the teacher and future researchers:

For teachers, the teachers should always be prepared if most of their students were anxious; because the teachers as a facilitator, should make a comfortable atmosphere in teaching and learning session. The teachers have to encourage and motivate their students while speaking in front of the class, especially in English classroom. Different learning styles can also be applied in the classroom by the teacher because every student needs more exercises to find their suitable way of learning. For example, the teacher can teach in the classroom by using Communicative Language Teaching. This method is to helps students communicate more effectively ad correctly in realistic situations that they may find themselves in. this type of teaching involves focusing on important functions like suggesting, thanking, inviting, complaining and asking for something.

For further researchers, for the next research, seeing the role of anxiety in speaking, the researcher suggests for further researcher to conduct research in the future to research on anxiety in different skills such as writing, reading and listening. However, the researcher suggests for further researcher not to put a "neutral" option on the questionnaire (as a research instrument) because this will only make students more likely to choose this option because it will be considered as a safe move for the students from getting a result out of their expectations.

\section{References}

Alsowat, H. (2016). Foreign language anxiety in higher education: a practical framework for reducing FLA. Collage of Education, Taif University, Saudi Arabia. European Scientific Journal. 12 (7), 193.

Amini, A., Elfrida, \& Kasmaini (2019). A correlation between students' anxiety levels and oral presentation performance in EFL speaking class. Journal of English Education and Teaching. 3 (3) 408-410.

Brown, H. D. (1994). Breaking the language barrier. Yarmouth: Intercultural Press, Inc.

Catur, W. (2019). Students' difficulties in speaking english at the tenth grade of sekolah menengah kejuruan. Universitas Muhammadiyah Purworejo. Journal of English Education and Teaching. 3 (4), 536-537 
Deyuan, H. (2011). Foreign language speaking anxiety: An investigation of non- English majors in mainland China. City University of Hongkong, Hongkong.

Diani, I., Yunita, W., \& Syafryadin, S. (2019). Interferensi Bahasa Indonesia terhadap Kemampuan Berbicara Bahasa Inggris Mahasiswa Universitas Bengkulu. In Seminar Nasional Pendidikan Bahasa dan Sastra (pp. 164-173).

Halgin, R. P., and Whitbourne, S. K. (2007) Abnormal Psychology: Clinical Perspectives on Psychological Disorders. New York: McGraw-Hill. 148.

Horwitz, E. K., Horwitz, M. B., and Cope, J. (1986).Foreign language classroom anxiety.The Modern Language Journal.70(2), 125- 132.

Keramida, A. (2009). Helping Students Overcome Foreign Language Speaking Anxiety in the English Classroom: Theoretical Issues and Practical Recommendations. International Education Studies Journal. 2 (4).

MacIntyre, P.D., and Gardner,R.C.(1994).The subtle effects of language anxiety on cognitive processing in the second language. Language Learning, 44, 283-305.

Mak (2009). An exploration of speaking-in-class anxiety with Chinese ESL learners.System.39.202-204.

Mayangta, T. 2013. Students' speaking anxiety in an EFL classroom. Universitas Pendidikan Indonesia, Jakarta.

Noermanzah, N., Syafryadin, S., Castrena, O. W., \& Abid, S. (2020). Rhetoric Structure of the Master of Ceremony and the Function of the Akikah Event in Lubuklinggau City. Journal of English Education and Teaching, 4(2), 232-247. doi:10.33369/jeet.4.2.232-247

Noermanzah, et al. (2020). "The Rhetorical Structure of the Lubuklinggau Mayor's Speech in Building Community Trust." International Journal of Progressive Sciences and Technologies (IJPSAT), 19(2), 146-154.

Ormrod, J. E. (2011) Educational Psychology: Developing Learner. Boston: Pearson Education Inc.

Passer, M. W., and Ronald E. S. (2009).Psychology: The Science of mind and behavior. New York: McGraw-Hill.

Phillips, E. (1992). The effects of language anxiety on students ${ }^{\text {ee }}$ oral test performance and attitudes. The Modern Language Journal, 76, 14-23.

Price, M. L. (1991). The subjective experience of foreign language anxiety: Interviews with highly anxious students. In E. K. Horwitz \& D. J. Young (Eds.), Language anxiety: From theory and research to classroom implications (pp. 101-108). Englewood Cliffs, New Jersey: Prentice-Hall. 
Susetyo, B. (2012). Statistika untuk Analisis Data Penelitian. Bandung: PT Refika Adimata.

Sutarsyah, C. (2017) An Analysis of Students' anxiety and Its Effect on Speaking Performance. Indonesian Journal of English Language Teaching and Applied Linguistics, 1 (2). pp. 143-152. ISSN 2527/6492.

Syafryadin, I. N. R., \& Widiastuti, R. (2013). Improving grade X students' speaking achievement under Round Robin technique. International Journal on Education, 1(1).

Syafryadin, Dian, E. C. Wardhana., Eka Apriani., \& Noermanzah. (2020). Maxim Variation, Conventional, and Particularized Implicature on Students' Conversation. International Journal of Scientific and Technology Research, 9(2) https://doi.org/10.31219/osf.io/cza8y.

Syafryadin, S. (2020). Students' Strategies in Learning Speaking: Experience of Two Indonesian Schools. Vision: Journal for Language and Foreign Language Learning, 9(1), 34-47. doi:http://dx.doi.org/10.21580/vjv9i14791

Ula, Ati Saidatul. (2016) An Analysis Of Speaking Anxiety In The Production Of English In Speaking Class English And Education Department Of Teacher Training And Education Faculty State Institute For Islamic Studies (Iain), Salatiga.

Woodrow, L. J. (2006). Anxiety and speaking English as a second language. Regional Language Centre Journal, 37(3), 308-328.

Zhang R, Zhong J (2012). The hindrance of doubt: Causes of language anxiety. Int. J. English Linguist, 2(3), 27-33. doi:10.5539/ijel.v2n3p27 